\title{
COMPETITIVENESS OF THE LUZNAVA MANOR
}

\author{
Iveta Dembovska \\ Lienīte Litavniece \\ Inese Silicka \\ Rezekne Academy of Technologies, Latvia
}

\begin{abstract}
Customers become increasingly demanding due to globalization processes. This fact affects competitors to fight for better tourism products. The need for innovations in the market that can attract tourists increases and creates the competitive advantage. The most important elements that can form and develop the competitive advantage by using different skills are efficiency, quality, innovation, and satisfaction of customers' expectations. The paper is the result of the RTA scientific grant "Feasibility study of tourism product development for the Luznava Manor" programme. The aim of the paper is to explore and analyse the theoretical aspects of the competitive advantage and to identify innovations for improving the competitiveness of the Luznava Manor. The most important elements of the competitive advantage in the tourism industry have been studied, information on foods used at the beginning of the 20th century and recipes characteristic of Latvia in the period of time when the Kierbedz family lived in the Luznava Manor have been researched and summarized. It has been offered to supplement the soup assortment at the Luznava Manor with a cold salty soup 'batvin' or 'holodnik' of the authentic recipe and name, as well as a plan of communication measures to increase competitiveness has been proposed.

Monographic, logical construction, scientific induction and deduction methods and a structured interview have been applied.
\end{abstract}

Keywords: competitiveness, competitive advantage, the Luznava Manor, tourism.

\section{Introduction}

Understanding of the concept "competitiveness" differs, and it is reflected in the research studies of various authors. There is no universal and precise definition. A review of the literature from Adam Smith to Michael Porter reveals that the term "competitiveness" has evolved from the conditions of resource availability and technology (comparative advantage) to the deployment of resources adjusting to customer preferences (competitive advantage).

Studies related to the competitiveness concept reveal important aspects, and one of them is that competitiveness takes place at various levels (company, region, country) (Hong, 2008). The pillars of tourism and travel competitiveness (in total 14) subjected to the national competitiveness have been defined in the Travel and 
Tourism Competitiveness Report 2015. They are the following: 1. Business Environment; 2. Safety and Security; 3 . Health and Hygiene; 4. Human Resources and Labour Market; 5. ICT Readiness; 6. Prioritization of Travel \& Tourism; 7. International Openness; 8. Price Competitiveness in the T\&T Industry; 9. Environmental Sustainability; 10. Air Transport Infrastructure; 11. Ground and Port Infrastructure; 12. Tourist Service Infrastructure; 13. Natural Resources; 14. Cultural Resources and Business Travel (Crotti\&Misrahi, 2015). Based on the works of such researchers of the competitiveness of enterprises as Baeva D.A. and Chernov V.B. (Баева \& Чернов, 2010), Vihanskyi O.S., Mincberg G., Porter M. (Виханский, 2010), a number of competitiveness types can be distinguished: actual, potential, product competitiveness, operational competitiveness that includes the current operational efficiency and adaptive operational efficiency. The matters of competitiveness improvement, marketing and strategic management have been researched by such Russian authors as Baeva D.A. and Chernov V.B. (Баева \& Чернов, 2010), Vihanskyi O.S. (Виханский, 2010), Kabushkin N.I. (Кабушкин, 2009) as well as Porter M. and Ketels C. (Porter\&Ketels, 2003).

The aim of the research is to explore and analyse the theoretical aspects of the competitive advantage and to identify innovations for improving the competitiveness of the Luznava Manor.

The tasks implemented in order to achieve the aim:

- the theoretical literature on the concept of competitiveness has been studied;

- the elements of the competitive advantage in the tourism industry have been researched;

- information on foods used at the beginning of the 20th century and recipes characteristic of Latvia in the period of time when the Kierbedz family lived in the Luznava Manor have been explored and summarized;

- $\quad$ suggestions of innovations in the Luznava Manor - to supplement the fish soup assortment of the authentic recipe and name - and a plan of communication measures to increase competitiveness have been proposed.

The research methods: monographic, logical construction, scientific induction and deduction methods, a structured interview.

\section{Research and discussion}

Competitiveness is inextricably linked to the notion of competition, expressing, overall, the capacity of persons, companies, economies or regions to maintain themselves in the local or international competition and to benefit from 
it (Gabor et al., 2012). Competitiveness means productivity, seen as added value. It has a dynamic character, forcing companies to give up inertia and foster innovation. Other various concepts - reduced cost of work force, low taxation, currency depreciation, increased exports and abundant natural resources - are either the result of increased competitiveness or potential stages of competitive development (Kardos, 2010). Competitiveness has become the focus of considerable international debate, as policy makers are concerned to enhance the micro foundations of growth and prosperity (Porter\&Ketels, 2003).

Caurkubule Z. and Vishnevska A. describe the concept competitiveness as a set of properties and characteristics that determines the success of a product in the particular market and the current moment. Thus, this concept is relative, strictly linked to the market and the time of the sale (Caurkubule \& Višnnevska, 2006). Competitiveness is a relative concept. A product, which is competitive in a particular market, may not be so popular in a different market. Also, sometimes a product in a market is competitive only in a certain period of time. The competitiveness of a product is a characteristic of a particular product that describes the actual or potential degree of satisfaction of specific needs, compared with similar products in a given market. However, the competitiveness of a company is the company's actual and potential capacity to design, produce and sell products in the existing conditions, providing prices and/or other factors, which are more attractive to a consumer in comparison with the competitors' products (Niedrītis, 2001). The competitiveness of a company is real and potential ability to engage in a battle with other market entities in order to achieve business goals (Баева \& Чернов, 2010).

A company, having better knowledge of what the customers' needs are and how they can be satisfied, is more competitive in business. It is not enough to know what services or products are being produced by a company. Both goods and services develop a business only when they are demanded for satisfaction of the individuals' desires and needs. There is no competitiveness without demand and no business practically (Niedrītis, 2001).

Competitiveness has been identified in the tourism literature as a crucial factor for the success of tourist destinations (Croes, 2010).

The debate on the definition of competitiveness also spans four components: ability to deploy resources, memorable experience of tourists, superior performance, and results (improving quality of life of the residents) (Croes \& Kubickova, 2013). Zhilkova J.V. (Жилкова, 2010), Kotler P. (Kotlers, 2007) and other authors have researched and analysed competitive advantages in tourism.

Tourism competitiveness is comprised of two concepts: tourism and competitiveness. Tourism displays several features that distinguish it from other exportable goods. Tourism is a product that covers the whole destination. Consumers are in search of an experience and therefore need to move to consume 
the product, i.e., it is the consumer who moves to the product for its consumption rather than the other way around. Interindustry competition (airlines, hotels, facilities, conventions, events, etc.) is dependent upon and derived from the choices made by tourists between alternative destinations. Competition therefore focuses on the tourism destination, i.e., the destination is the unit of analysis (Croes, 2010).

The following key competitiveness indicators can be distinguished:

Price competitiveness. Tourists consider the price (cost of living) at the destination relative to the costs of living at the origin and substitute destinations. Thus, two types of prices have to be considered in estimating the price competitiveness of a destination. The first one is relative price between the receiving and the origin country; the second is relative price between different competing destinations, which generates the substitution price effect. Tourism price competitiveness is essentially a matter of the prices of the goods and services that tourists buy, expressed in some common currency. Several factors impinge in different ways on tourism price competitiveness: exchange rates, inflation and overall price levels, labour prices, productivity performance of tourism industries, export booms, tax levels and structures, infrastructure charges, fuel prices and taxation, environmental charges (Forsyth \& Dyer, 2009).

Quality competitiveness. As the biggest advantage of its production, a company considers compliance of the essential peculiarities, characteristics and durability values with the conditions or rules that differentiate its products from the ones offered by competitors, leaving the price in the background. An important factor in the quality competitiveness is that a client feels that the benefits he/she gets by purchasing the company's products is more important than the price, that is, money he/she spends on the product. Implementation of the quality competitiveness requires marketing experience, an extensive innovation portfolio, leadership in technologies, industry knowledge, business contacts with sales channels. Management should focus on quality control and attraction of qualified personnel. There are also a number of risk factors, for example, competitors can learn the unique characteristic of the product and start a price war, or, in the case of lack of an explanatory advertising, a company cannot achieve the expected success (Caune, 2005).

Service competitiveness. A company considers good service as its main advantage. Comparing the company's competitive advantages, good service is the most difficult to be created and also the most difficult to be copied. It is not possible to simply take it over because good service is an organized and regular work that results in customer service to become the main factor in the competitiveness of enterprises. Operations taking place in the services sector are very similar, so often service specifically, rather than a company's advertisement or products and prices, determines a customer's choice. Improvement of the 
customer service is like a never-ending rivalry between customers' needs and the service offered by a company. Companies, who have a good understanding of their customers' priorities and offer adequate service, are more successful in competition, and it helps companies to improve their position in the market. It is also connected with a human resources indicator. The human resources indicator measures the quality of the labour force in the destination country in terms of educational and related criteria, as better-quality labour can provide betterquality tourism services (Gooroochurn \& Ugiyarto, 2005).

A competitive company is a company that has its own competitive advantage. The competitive advantage is a value-generating activities and resources that ensure profitability above the average level of industry profitability and are able to keep it for many years. The process of competitive advantage assurance can be divided into two parts: creation of a competitive advantage and development of the competitive advantage (Caune, 2005).

The company's internal environment is the one that determines the company's competitive advantage, the content of which consists of the company's resources and capabilities. A company might have valuable resources but, if there is a lack of abilities to use them expediently in order to achieve its objectives, a company will not be able to reach and maintain different skills. The different skills are its strength, allowing the company to achieve and implement strategies that ensure a high level of efficiency, quality, innovation and full satisfaction of clients' needs, which all may cause or continue to develop the competitive advantage.

The communication strategy and promotion measures have an important role in the increase of competitiveness. Freijers V. has defined the division of the communication instruments: corporate identity, sales promotion, public relations, and advertising (Freijers, 2011). Freijers offers a service phase model of communication measures set that offers to develop each communication tool to attract customers in the potential phase, the process phase, and the result phase (Freijers, 2011). Set of communication measure is a tool for increasing price, quality and service competitiveness.

It can be concluded that competitiveness is very important to enterprises, since it determines the success of a product in the particular market and the current moment. Competitiveness is a set of a company or product characteristics, compelling customers to choose the supply of a corresponding company; the choice could be based on price, quality or service culture.

The Luznava Manor, as a relatively new tourism object, is still in its development process, meaning that active work is currently taking place in order to select the company's business strategy in the changing market, consequently, to improve its competitiveness. 
The Luznava Manor is the newest tourism destination in Rezekne municipality, which was opened for visitors on April 25, 2015 after the reconstruction. The manor's reconstruction goals are to maintain the cultural and historical heritage and offer a space for organizing events and receptions in an authentic style. The Luznava Manor operates as an international environmental education and art centre and a place for open air art events, seminars, and camps. However, in order to implement and develop an offer, it needs to be understood what a current customer needs and what attracts a potential visitor. The improvement of the image, product and quality takes place at the moment (conclusion is formed on the basis of the conducted structured interviews (direct, April, 2016) with I. Balcune, the manager of the Luznava Manor, within the framework of the project " Feasibility Study of Tourism Product Development for the Luznava Manor").

Events at the Luznava Manor are organized, and foreign guests are being invited to participate, for example, a piano concert of Rokas Zubovas, the greatgrandson of M. Ciurlionis (Lithuania); Pascal Valois, a Canadian guitarist; an ancient music concert by I. Grudule and V. Fluckiger (Switzerland); the Baroque music performed by Czech and Swiss musicians. Cooperation with Poland, Lithuania, Hungary takes place as well: exhibitions have been set up, thanks to the cooperation with the foreign embassies. The Luznava Manor is also presented to international tourist groups and tour operators who visit Rezekne municipality. Information about the Luznava Manor is translated into the Latvian (LV), Latgalian (LTG), Russian (RU) and English (ENG) languages in order to reach a wide range of audience. It should be noted that only basic information is available in LTG, RU and ENG, a summary of future events or articles about previous events are not published in these languages. However, I. Balcune, the manager of the Luznava Manor, plans to provide information in Lithuanian and Polish as well.

The existing supply range mainly consists of cultural events, tours and workshops, fish soup cooking and tasting for groups are being offered by prior arrangement. A visitors' survey was carried out on supply range of the Luznava Manor and its development opportunities; it was concluded that visitors (survey was organized in April - May, 2016, total number of respondents are 50) of the Luznava Manor would like to have services such as lessons, master classes, and outdoor activities for the whole family. Since the importance of experiences in tourism is increasing, visitors would like to enjoy the offer of authentic products.

The authors conducted a study within the framework of the project on the foods, recipes and eating habits at the beginning of the 20th century in Latvia that were characteristic of the period of time when Kierbedz family lived in the Luznava Manor. It is being offered to complement the soup assortment with a cold salty soup - 'batvin' or 'holodnik'. 
The main occupation of Latgale population in the 18th and 19th centuries was agriculture. A smallholder of farmers was the dominating form; they were created when land was divided between sons of the succession rights. Small pieces of land could not provide a living wage, so crafts developed widely, craft centres with a certain specialization appeared. Pottery was more developed in Silajani, Andrupene, Ludza neighbourhood, Vilaka, woodworking - in Andrupene, Kaunata, Dagda, Kraslava, Izvalta, Silajani, fishing-net making - in Andrupene. In addition to agriculture, the communities located close to lakes engaged in fishing. The ethnic composition of the rural population was very variegated Latvians, Russians, Belarusians, Poles, Lithuanians, Jews; the traditional cuisine was varied in cooking nuances through the usage of the same products.

Exploring the statistical yearbook of Latvia 1921, it can be concluded that the main foodstuffs produced in the area were the following: cereals (rye, wheat, barley, oats) and goods made from these cereals (flour, groat); potatoes, peas, beef, veal, mutton, pork and meat products (smoked pork, pig fat); butter, cottage cheese, milk, eggs. Vegetables were grown in home gardens for personal needs. Berries and mushrooms harvested in forests were used widely (the State Statistical Bureau..., 1922).

Cookbooks published in the German language were used in the territory of Latvia in the 18th century. Since Latvian farmers worked as cooks in manors, cookbooks in Latvian were required. Therefore, two editions were published almost at the same time. Priest and publisher Christoph Harder (1747-1818) translated a book called "Tā pirmā pavāru grāmata, no vāces grāmatām pārtulkota" ["The first cookbook, translated from German books"] in 1795, Rubene. A second cookbook was printed in the typography of Johann Friedrich Steffenhagen (1744-1812) - „Latviska pavāru grāmata muižas pavāriem par mācību visādus kungu èdienus gardi vārīt un sataisīt" ["Latvian cook book for manor chefs for learning how to cook deliciously all kinds of noblemen dishes"] in 1796, Jelgava. Lestene pastor Friedrich Casimir Urban (1765-1796) began to translate and compile a book from a number of German cook books, but, after his death, it was completed by Jelgava pastor and writer Matthias Stobbe (1742-1817) (Bermonte, 2009).

In June 2016, a book "Muižas zupas" ["Manor soups"] by Inga Pauline (Praulina, 2016) was published. It contains information from the cookbook "Latvian cook book for manor chefs for learning how to cook deliciously all kinds of noblemen dishes" (published in Steffenhagen J.F. typography in 1796). The book includes three kinds of soups: hot or salty soups, hot dessert soups and cold dessert soups.

Based on the above mentioned conclusions, the authors suggest improving the offered fish soup assortment with a cold salty soup - 'batvin' or 'holodnik' in order to raise the competitiveness of the Luznava Manor. The cold salty soup 
('batvin' or 'holodnik') - the Slavic names of dishes in Latgale show the influence of the eastern neighbour. However, there were important differences in the cooking process: the cold soup of the Slavic nations was based on beet broth, but the Latvians of Latgale - mostly used sour milk with boiled beets or beet leaves. 'Batvin' or 'holodnik' was prepared during the hot summer days, and people ate it with dry potatoes or bread. Cooking nuances: "Grate boiled beets, cut fresh cucumbers, grind spring onions, and add all these products to sour milk. Add a bit of salt. Add sour cream before eating" (Ludza). "Stew beet leaves in an oven, rinse, cut with a knife and pour cold water. Add dill, fresh cucumbers, spring onions, sour milk, sour cream "(Kaunata). "In the hay time, they boiled 'bacvin' (beetroots), 'kolodnik' (soup) and ate all day" (Malta) (Dumpe, 1998).

Complementing the tourism product with experiences that include knowledge, involvement, uniqueness, meaningful experiences, stories and adventures, the competitiveness of the Luznava Manor can be improved.

The competitiveness of enterprises is formed and can be raised by a number of factors, including a developed plan of communication measures. In order to advance the Luznava Manor in the market successfully and increase its competitiveness, a communication measures plan in the service phases model was formed, based on the model developed by Freijers V.

All the means of communication tools can be used to improve competitiveness: advertising, public relations, corporate identity, and sales promotion.

Table 1 Set of communication measures of the Luznava Manor in the service phases model (by the authors, based on Freijers, 2011)

\begin{tabular}{|c|c|c|c|}
\hline \multicolumn{4}{|c|}{ Phase-oriented communication policy } \\
\hline & Potential phase & Process phase & Result phase \\
\hline 1. & 2. & 3. & 4. \\
\hline $\begin{array}{l}\text { Tools of } \\
\text { communication } \\
\text { policy }\end{array}$ & $\begin{array}{l}\text { Communication of } \\
\text { potential factors }\end{array}$ & $\begin{array}{l}\text { Communication } \\
\text { with a client in } \\
\text { service provision } \\
\text { moment }\end{array}$ & $\begin{array}{l}\text { Communication of } \\
\text { results (after } \\
\text { service provision) }\end{array}$ \\
\hline $\begin{array}{l}\text { Corporate } \\
\text { identity }\end{array}$ & $\begin{array}{l}\text { Image, brand } \\
\text { building } \\
\text { (to participate in the } \\
\text { market (exhibitions, } \\
\text { presentations, } \\
\text { conferences) as a } \\
\text { culture carrier, to } \\
\text { convince a customer to }\end{array}$ & $\begin{array}{l}\text { Corporate } \\
\text { behavior } \\
\text { (possibility to meet } \\
\text { the manager of the } \\
\text { Luznava Manor and } \\
\text { form a direct } \\
\text { communication with } \\
\text { clients) }\end{array}$ & $\begin{array}{l}\text { Image building } \\
\text { (hospitable } \\
\text { welcoming of } \\
\text { clients, } \\
\text { communication in a } \\
\text { language } \\
\text { convenient to a } \\
\text { client) }\end{array}$ \\
\hline
\end{tabular}




\begin{tabular}{|c|c|c|c|}
\hline & $\begin{array}{l}\text { choose events in the } \\
\text { Luznava Manor: } \\
\text { performances of } \\
\text { popular, professional } \\
\text { artists, elegant } \\
\text { concerts in Art } \\
\text { Nouveau style with } \\
\text { wine tasting, etc.) }\end{array}$ & & \\
\hline Public relations & $\begin{array}{l}\text { Creation of trust, } \\
\text { image building } \\
\text { (publication of events' } \\
\text { plan in newspapers, } \\
\text { magazines, websites, } \\
\text { emphasizing the } \\
\text { enjoyment of an event } \\
\text { in Art Nouveau } \\
\text { atmosphere; } \\
\text { development of a } \\
\text { booklet of a monthly } \\
\text { action plan (in } \\
\text { LV,LTG,ENG,RU } \\
\text { languages)) }\end{array}$ & $\begin{array}{l}\text { Communication of } \\
\text { clients, internal } \\
\text { marketing (offer of } \\
\text { the opportunity to } \\
\text { make a suggestion } \\
\text { or complaint in a } \\
\text { book, emphasizing } \\
\text { that each visitor's } \\
\text { expectations are } \\
\text { crucial) }\end{array}$ & $\begin{array}{l}\text { Communication of } \\
\text { results, internal } \\
\text { marketing (interest } \\
\text { in visitors' } \\
\text { satisfaction after } \\
\text { events, creating an } \\
\text { article for } \\
\text { publication, } \\
\text { mention their names } \\
\text { and opinions) }\end{array}$ \\
\hline Sales promotion & $\begin{array}{l}\text { Personal selling } \\
\text { (participation in the } \\
\text { exhibition-fair } \\
\text { "Balttour", } \\
\text { presentations in } \\
\text { international } \\
\text { conferences, for } \\
\text { example, RTA } \\
\text { scientific conferences) }\end{array}$ & $\begin{array}{l}\text { Sales of additional } \\
\text { services } \\
\text { (Horseback riding, } \\
\text { bicycle rent and } \\
\text { excursions in the } \\
\text { park) }\end{array}$ & $\begin{array}{l}\text { Granting of } \\
\text { discount coupons } \\
\text { for the future } \\
\text { events, promo } \\
\text { offers }\end{array}$ \\
\hline Advertising & $\begin{array}{l}\text { Special attention to } \\
\text { target groups } \\
\text { (formation of and } \\
\text { information about } \\
\text { events to each target } \\
\text { group: youth and } \\
\text { students-conferences } \\
\text { and business seminars; } \\
\text { families with children- } \\
\text { active leisure in the } \\
\text { park, excursions, } \\
\text { workshops; middle-age } \\
\text { people and seniors- } \\
\text { excursions concerts, } \\
\text { exhibitions, thematic } \\
\text { evenings, tastings - }\end{array}$ & & $\begin{array}{l}\text { After sales } \\
\text { advertising(inform } \\
\text { ation about the } \\
\text { future events, } \\
\text { souvenir sale, } \\
\text { issuance of leaflets } \\
\text { on the future } \\
\text { events) }\end{array}$ \\
\hline
\end{tabular}




\begin{tabular}{|l|l|l|l|}
\hline & $\begin{array}{l}\text { fish soup; creation of } \\
\text { a video advertisement; } \\
\text { association of The } \\
\text { Luznava Manor with } \\
\text { the phrases: a pearl of } \\
\text { culture, a place for } \\
\text { music and culture, } \\
\text { sounds of nature in the } \\
\text { park, a place where } \\
\text { Muse inspires } \\
\text { everyone. }\end{array}$ & & \\
Important & & \\
\hline
\end{tabular}

\section{Conclusions}

Competitiveness of tourism industry consist of separate tourism product competitiveness and competitiveness of all tourism industry.

It can be concluded that competitiveness is very important to enterprises, since it determines the success of a product in the particular market and the current moment. Competitiveness is a set of a company's or product's characteristics, compelling customers to choose the supply of a corresponding company; the choice could be based on price, quality or service culture.

The existing supply range mainly consists of cultural events, tours and workshops; fish soup cooking and tasting for groups are being offered by prior arrangement. A visitors' survey was carried out on the supply range of the Luznava Manor and its development opportunities; it was concluded that visitors of the Luznava Manor would like to have services such as lessons, master classes, and outdoor activities for the whole family. Since the importance of experiences in tourism is increasing, visitors would like to enjoy the offer of authentic products.

The authors conducted a study within the framework of the project on the foods, recipes and eating habits at the beginning of the 20th century in Latvia that were characteristic of the period of time when Kierbedz family lived in the Luznava Manor. It is being offered to complement the soup assortment with a cold salty soup - 'batvin' or 'holodnik'.

Complementing the tourism product with experiences that include knowledge, involvement, uniqueness, meaningful experiences, stories and adventures, the competitiveness of the Luznava Manor can be improved.

In order to increase the competitiveness of the Luznava Manor, a communication measures plan has to be developed and implemented. When creating a marketing strategic action plan for expansion in the market based on the phase model of communication measures set, the managers will be able to 
monitor and evaluate the strategic activities in each of the phases and, if necessary, make changes. Set of communication measure is a tool for increasing price, quality and service competitiveness.

\section{References}

Bermonte, I. (2009). Kulinārijas nozares Laviskās terminoloğijas aizsākumi 18.gadsimta beigās. Liepājas Universitāte, Latvija ISSN 1822-7708

Caune, J. (2005). Konkurētspējīgas priekšrocības radīšanas, attīstī̌̌anas un pārně̌anas metodika Latvijas uznēmumos.Retrieved from http://www3.acadlib.lv/greydoc/ Caunes.disertacija/Caune -lat.doc

Caurkubule, Ž., Višnnevska, A.(2006). Mārketinga pamati. Rīga: Merkūrijs LAT.

Croes, R. (2010). Small Island Tourism Competitiveness: Expanding Your Destination's Slice of Paradise. Retrieved from: https://hospitality.ucf.edu/files/2011/09/Version-2-SmallIsland-Tourism-Competitiveness_Jan07_2010.pdf

Croes, R., Kubickova, M. (2013). From potential to ability to compete: Towards a performancebased tourism competitiveness index. Journal of Destination Marketing \& ManagementVolume 2, Issue 3, (pp. 146-154). Retrieved from http://ac.elscdn.com/S2212571X1300036X/1-s2.0-S2212571X1300036X-

main.pdf? tid=7d639c2c-dbd8-11e6-ac3e00000aab0f26\&acdnat $=1484563534$ 5e020e3dc45a4c403ce9f1c4158bbe41

Crotti, R., Misrahi, T. (2015). The Travel \& Tourism Competitiveness Index 2015: T\&T as a Resilient Contribution to National Development. World Economic Forum. Retrieved from http://www3.weforum.org/docs/TT15/WEF_TTCR_Chapter1.1_2015.pdf

Dumpe, L. (1998). Latviešu tradicionālā piensaimnieč̄ba. Piena produkti un piena èdieni. Rīga: Latvijas vēstures institūta apgāds.

Forsyth, P., Dyer, L. (2009). Tourism Price Competitiveness. Retrieved from: https://www.researchgate.net/profile/Larry_Dwyer/publication/265824711_Tourism_Pr ice_Competitiveness/links/5476ec200cf245eb43728d81.pdf

Freijers, V. (2011). Tūrisma mārketings. Uz tirgu orientēta tūrisma mikroekonomikas un makroekonomikas pārvaldība. Rīga: SIA "Biznesa augstskola Turība".

Gabor, M.R., Contiu, L.C., Oltean, F.D. (2012). A comparative analysis regarding European tourism competitiveness: emerging versus developed markets. Economics and Finance 3 (pp. 361 - 366) Retrieved from: http://ac.els-cdn.com/S2212567112001657/1-s2.0S2212567112001657-main.pdf?_tid=818ca084-dbc7-11e6-aa1000000aacb360\&acdnat $=148455 \overline{6} 240 \_$e1e5dfb70fc98b9722286e930e180864

Gooroochurn, N., Ugiyarto, G. (2005). Competitiveness Indicators in the Travel and tourism industry. Tourism Economics 11 (1), 25-43

Hong, W. (2008). Competitiveness in the tourism sector. Germany:Springer, Heidelberg.

Interview with I. Balčūne.

Kardos, M. (2010). The Issue of competitiveness. Romania's Competitive Positioning in Global Context. Analele Universitāti “Ovidius”, Seria: Stiinte Economice, Volume X, Issue 1, (pp 91-96).

Kotlers, F. (2007). Kotlers par mārketingu. Rīga: SIA „Lietišķās informācijas dienests”.

Mellina, M. (1904). Lauksaimnieču pavārgrāmata. Smiltene, 1904. 22. Nodalas Oriğināldizainu atjaunojusi Inguna Kḷava : Melanija Mellina LAUKSAIMNIEČU PAVĀRGRĀMATA Redaktore Gundega Sēja Apgāds Zvaigzne ABC, SIA, 
K. Valdemāra ielā 6, Rīgā, LV-1010. Red. nr. DG-104e.C Apgāds Zvaigzne ABC, SIA ISBN 978-9934-0-2699-7

Niedrītis, J.Ē. (2001). Mārketings. Otrais, papildinātais izdevums. Rīga: Biznesa augstskola Turība.

Porter, M.E., Ketels, C.H.M. (2003). UK Competitiveness: Moving to the Next Stage. Department of Trade and Industry Economics. Paper No 3, Department of Trade and Industry, LondonTourism Industry. Tourism Economics, 11 (1), (pp.25-43). Retrieved from: http://journals.sagepub.com/doi/pdf/10.5367/0000000053297130

Prauliņa, I. (2016). Muižas zupas. Jelgava, SIA "Jelgavas tipogrāfija"

Valsts statistikas pārvalde. (1922). Latvijas statistikas gada grāmata-1921. Rīga, 1922.gadā.

Баева, Д. А., Чернов В.Б. (2010). Управление конкурентоспособ- ностью промышиленного предприятия / Д.А. Баева, В.Б. Чернов. - Челябинск: Издательский центр ЮУрГУ.

Виханский, О.С. (2010). Менеджмент: человек, стратегия, организация.- М.: Банки и биржи. ЮНИТИ.

Жилкова, Ю.В. (2010). Влияние демографической обстановки в России на развитие детского туризма / Ю.В. Жилкова, 3.В. Киримова // Всероссийская научнопрактическая конференция «Пути развития и совершенствования детскоюношеского, молодежного и спортивно-оздоровительного туризма». Москва, 4-5 декабря 2010 года / И.А. Дрогов (отв. ред.) - М.: ГУУ, 2010. (С. 149-151).

Кабушкин, Н.И.(2009.) Менеджмент туризма . Мн.: Новое знание. 